\title{
River runoff variability at watercourses of the Ural river basin
}

\author{
Regina Fatkhutdinova ${ }^{*}$, Diana Gareeva \\ Bashkir State University, Zaki Validi 32, 450076, Ufa, Russia
}

\begin{abstract}
The article is devoted to spatial and temporal variabilities of the river runoff on the example of the river Ural within the territory of the Russian Federation. The author points out the necessity of investigating fluctuations in the water resources of a transboundary river for the purposes of long-term water management planning. Using the coefficient of variation and asymmetry, the annual runoff variability is analyzed.
\end{abstract}

\section{Introduction}

The rational use of water resources requires reliable data on the long-term variability of the quantitative characteristics of the river runoff. In this respect, it becomes necessary to conduct research on studying the multiannual runoff dynamics of individual river systems. Given the increasing volumes of water consumption, special relevance is attributed to identifying the trends in river runoff variations. While determining long-term changes in the water content, special attention is paid to the annual and maximum discharges [1]. The annual average throughflow values are used for identifying the river runoff rate, which serves as the basis of long-term water management planning. The data related to the absolute values of the maximum throughflow is needed primarily for preventing negative implications - the formation of floods, the water-logging of settlements, and the damaging of hydrotechnic facilities.

The subject of research comprises the selected segments of the upper and middle reaches of the river Ural, including the meridional section within the Republic of Bashkortostan and the Chelyabinsk Region (the upper reaches of the river Ural) and the latitudinal section of the river in the Orenburg Region (the middle reaches). The examined area is characterized by the high water consumption volume [2-3], the strained water management conditions are aggravated due to specific climatic conditions [4]. The water regime of the river is characterized by the extremely uneven annual runoff distribution: the spring high water accounts for $62-98 \%$ of its volume [5]. The high degree of the river channel regulation is considered to be a distinctive feature of the Ural river basin. To some extent this facilitates leveling off the discrepancies observed in the annual distribution of water resources and in the formation of maximum runoff values, however, the effect exerted by the water-storage reservoir towards the water regime is ambivalent [3-5].

\footnotetext{
*Corresponding author: regishka1503@yandex.ru
} 


\section{Research data and methods}

The initial data processed includes the materials obtained through hydrological observations of at least 35 years. Among these, the previous 40-50 years belong to a period of intensive climate changes, which is also demonstrated by the results of our research conducted in the Republic of Bashkortostan and adjacent territories [6]. 33 active stream gauges were selected for analyzing the runoff variability of the Ural river basin. The longest data series making 85 years belongs to the stream gauge of the Kizilskoe village at the river Ural.

Based on the observational data [7-8], the coefficients of variation and asymmetry were used in the calculations on assessing the variability of annual and maximum runoff [7-8]. The given parameters were chosen as basic indicators of the river runoff variability. The calculations and graphing were carried out using software products designed by S.G. Dobrovolsky [8].

\section{Discussion}

According to the studied data [9], the values of the variation coefficient (hereinafter referred to as $\mathrm{C}_{\mathrm{V}}$ ) for the high-flow part of the study area, namely, for the Sakmara river basin, make 0.52-0.63. While the rate of stream flow decreases to the east, south, and southwest, CV values tend to increase to $0.72-0.83$ in the right-bank tributaries of the upper reaches of the river Urals and up to $0.90-1.14$ in the upper reaches of its left-bank tributaries. At that time the data analysis covered the period from the moment of starting observations to 1966.

However, longer series of observations have been analyzed, which may testify to the annual and maximum runoff variability (Table). The highest variation values in the annual runoff made 0.80-0.93 and were observed at the left-bank tributaries of the river Ural, such as the rivers Blyava, Zharly, Bolshaya Karaganka, Dzhusa and Kugutuk. The coefficient of variation for the given territory displayed a decrease by $0.20-0.30$. The variation coefficient to asymmetry coefficient ratio ranged from 1.90 to 2.71 .

For the right-bank tributaries of the upper and middle reaches of the river Ural the lowest values of the variation coefficient ranged from 0.38 to 0.50 and were observed at the rivers Bolshoy Kizil, Kasmarka, Zilair, Maly Kizil, Sakmara, Bolshoy Ik and Salmysh. In this case a decrease of 0.13-0.14 was observed.

Further in this study, the dependences between the variation coefficient of the annual runoff and physical and geographical factors were analyzed, which testifies to the existence of a quite close relationship between the coefficient of variation and the annual runoff rate, namely, the mean multiannual runoff depth. This is due to the fact that the given indicator reflects the impact exerted on runoff by both climatic and other physical and geographical factors.

In terms of bilogarithmic scales, the variation coefficient of the annual runoff at the rivers of the Ural river basin is dependent on the runoff depth (Fig.). The solid curved lines reflect approximation via the method of spatially weighted least squares. 
Table. Variation and asymmetry coefficients of the annual and maximum runoff of the Ural river basin.

\begin{tabular}{|c|c|c|c|c|c|c|}
\hline \multirow{2}{*}{ River - stream gauge } & \multirow{2}{*}{$\begin{array}{l}\text { Monitoring } \\
\text { period }\end{array}$} & \multirow{2}{*}{$\begin{array}{c}\text { Duration of } \\
\text { observations, } \\
\text { years }\end{array}$} & \multicolumn{2}{|c|}{$\begin{array}{l}\text { Annual } \\
\text { runoff }\end{array}$} & \multicolumn{2}{|c|}{$\begin{array}{l}\text { Maximum } \\
\text { runoff }\end{array}$} \\
\hline & & & $\mathrm{C}_{\mathrm{v}}$ & $\mathrm{C}_{\mathrm{s}}$ & $\mathrm{C}_{\mathrm{v}}$ & $\mathrm{C}_{\mathrm{s}}$ \\
\hline Ural - Verkhneuralsk & $1936-2017$ & 82 & 0,55 & 0,91 & 0,68 & 1,95 \\
\hline Ural - Kizilskoe & $1932-2017$ & 85 & 0,71 & 1,23 & 1,19 & 2,45 \\
\hline Ural-Berezovsky & $1948-2017$ & 70 & 0,65 & 1,35 & 0,91 & 2,01 \\
\hline Ural - Orenburg & $1935-2017$ & 83 & 0,73 & 1,46 & 1,54 & 3,45 \\
\hline $\begin{array}{l}\text { Mindyak - } \\
\text { Novobayramgulovo }\end{array}$ & $1961-2017$ & 57 & 0,51 & 1,02 & 0,64 & 1,33 \\
\hline Urlyada - Novoakhunovo & $1966-2017$ & 52 & 0,77 & 1,39 & 0,94 & 1,81 \\
\hline Maly Kizil - Murakaevo & $1959-2017$ & 59 & 0,48 & 1,55 & 1,06 & 4,24 \\
\hline $\begin{array}{l}\text { Bolshoy Kizil - } \\
\text { Burangulovo }\end{array}$ & $1966-2017$ & 52 & 0,49 & 0,80 & 0,82 & 2,16 \\
\hline $\begin{array}{l}\text { Bolshoy Kizil - Verkhne- } \\
\text { Abdryashevo }\end{array}$ & $1949-2017$ & 69 & 0,55 & 1,53 & 0,66 & 1,57 \\
\hline $\begin{array}{l}\text { Karagayly - Staro- } \\
\text { Sibaevo }\end{array}$ & $1966-2017$ & 52 & 0,66 & 1,61 & 0,96 & 3,23 \\
\hline $\begin{array}{l}\text { Bolshaya Karaganka - } \\
\text { Izmaylovsky }\end{array}$ & $1969-2017$ & 49 & 0,84 & 1,64 & 1,35 & 2,27 \\
\hline $\begin{array}{l}\text { Bolshaya Urtazymka - } \\
\text { Sosnovka }\end{array}$ & $1963-2017$ & 55 & 0,79 & 1,34 & 0,95 & 1,20 \\
\hline Suunduk - Maysky & $1970-2017$ & 48 & 0,69 & 0,88 & 0,95 & 1,52 \\
\hline Dzhusa - Iriklinsky & $1963-2017$ & 55 & 0,83 & 1,59 & 1,13 & 1,77 \\
\hline Tanalyk - Samarskoe & $1957-2017$ & 61 & 0,64 & 1,20 & 0,77 & 0,81 \\
\hline Tanalyk - Mambetovo & $1961-2017$ & 57 & 0,71 & 1,54 & 0,95 & 1,50 \\
\hline $\begin{array}{l}\text { Bolshoy Kumak - } \\
\text { Novoorsk }\end{array}$ & $1967-2017$ & 51 & 0,71 & 1,15 & 0,90 & 1,46 \\
\hline Zharly - Adamovka & $1951-2017$ & 67 & 0,90 & 2,44 & 0,94 & 1,67 \\
\hline Or - Istemes & $1956-2017$ & 62 & 0,73 & 0,77 & 0,80 & 0,96 \\
\hline $\begin{array}{l}\text { Sakmara - } \\
\text { Verkhnegaleevo }\end{array}$ & $1958-2017$ & 60 & 0,47 & 1,54 & 0,49 & 0,85 \\
\hline Sakmara - Akyulovo & $1944-2017$ & 71 & 0,47 & 0,76 & 0,47 & 0,63 \\
\hline Sakmara - Kargala & $1966-2017$ & 52 & 0,39 & 0,12 & 0,46 & 0,37 \\
\hline $\begin{array}{l}\text { Zilair (Urman-Zilair) - } \\
\text { Zilair }\end{array}$ & $1948-2017$ & 69 & 0,49 & 0,95 & 0,71 & 2,27 \\
\hline Chertanka - Zheltoe & $1953-2017$ & 65 & 0,61 & 1,13 & 0,97 & 1,36 \\
\hline Kasmarka - Utyagulovo & $1977-2017$ & 41 & 0,51 & 1,49 & 0,57 & 1,05 \\
\hline Bolshoy Ik- Mrakovo & $1953-2017$ & 65 & 0,42 & 0,95 & 0,52 & 1,06 \\
\hline Salmysh - Bulanovo & $1958-2017$ & 60 & 0,37 & 0,06 & 0,71 & 1,79 \\
\hline $\begin{array}{l}\text { Chernaya - Krasny } \\
\text { Kholm }\end{array}$ & $1955-2017$ & 63 & 0,72 & 1,73 & 0,77 & 1,33 \\
\hline Ilek - Vesely 1 & 1951-2017 & 67 & 0,57 & 1,25 & 0,92 & 2,97 \\
\hline $\begin{array}{l}\text { Khudolaz - } \\
\text { Chernyshevsky }\end{array}$ & $1978-2017$ & 40 & 0,60 & 1,01 & 0,95 & 1,36 \\
\hline Berdyanka - Pugachevsky & $1980-2017$ & 38 & 0,57 & 1,46 & 0,87 & 1,74 \\
\hline Blyava - Mednogorsk & $1983-2017$ & 35 & 0,94 & 1,87 & 1,11 & 2,44 \\
\hline Kugutuk - Dombarovsky & $1952-2017$ & 66 & 0,81 & 2,00 & 0,94 & 2,61 \\
\hline
\end{tabular}




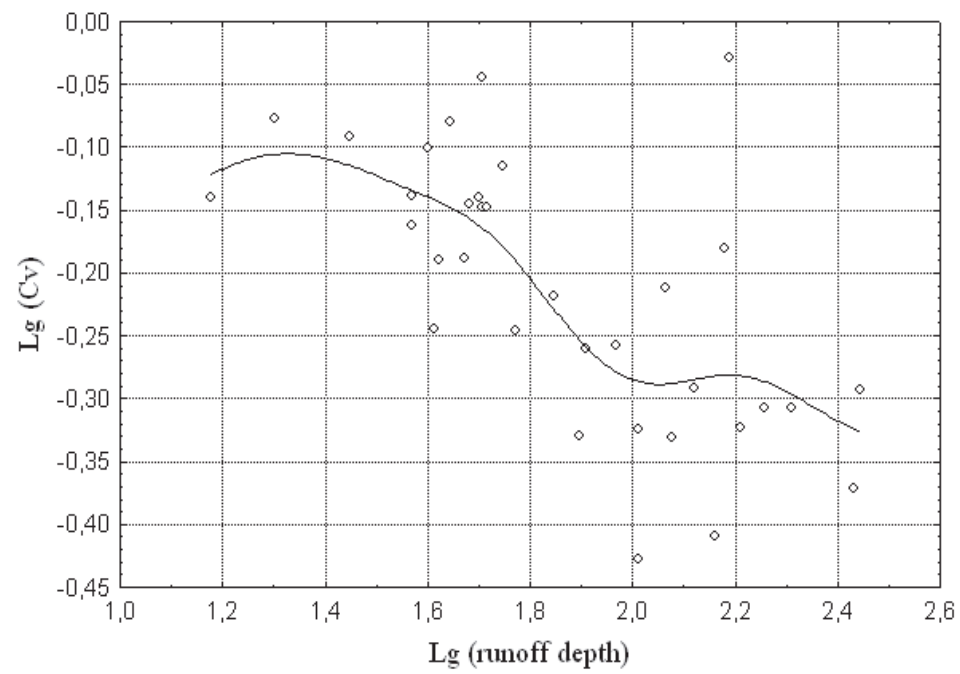

Fig. The correlation between the variation coefficient of the annual runoff $\operatorname{Lg}(\mathrm{Cv})$ and the mean multiannual runoff depth $\operatorname{Lg}$ (runoff depth), in bilogarithmic scales. The solid curve shows approximation under the method of spatially weighted least squares.

By means of bilogarithmic scales the Fig. reveals a dependence, whereby the variation coefficient of the annual runoff tends to decrease provided that the mean annual runoff depth of the Ural river basin increases.

The maximum river runoff variability of the Ural river basin was also evaluated as to the changes in the coefficient of variation and asymmetry. For 18 stream gauges, making about $50 \%$ of the total number, the variation coefficient values ranged from 0.90 to 1.54 . The highest values of the variation coefficient ranging from 1.06 to 1.54 and the highest values of the asymmetry coefficient ranging from 1.77 to 4.25 were observed at the river Ural - the city of Orenburg and at the villages Kizilskoe, Bolshaya Karaganka, Dzhusa, Blyava, Maly Kizil. Therein, on the contrary, we have observed an increase of $0.30-0.40$ compared with the data [9].

The minimum values of the variation coefficient for the maximum runoff ranging from 0.44 to 0.49 were observed at all stream gauges of the river Sakmara or on the largest rightbank tributary of the river Ural. However, according to the data [9], the coefficient of variation varied from 0.58 to 0.60 also for the river Sakmara, which shows that the indicator decreased by $0.11-0.14$.

\section{Conclusion}

In terms of the water regime, the Ural river basin is characterized by a distinctive predominance of the following features: runoff in spring, and low baseflow with heavy rainfall floods in summer. The calculations conducted reveal the following:

- there was an increase by $0.13-0.14$ in the variation coefficient of the annual runoff of the Ural river basin for left-bank tributaries and a decrease by $0.20-0.30$ for the right-bank tributaries;

- there was an increase by $0.11-0.14$ in the coefficient of variation of the maximum runoff of the Ural river basin for left-bank tributaries and a decrease by $0.30-0.40$ for the right-bank tributaries.

Currently, we observe a decrease in the annual runoff of the left-bank tributaries and an increase in the runoff of the right-bank tributaries, which results in an even more uneven 
distribution of runoff in the Ural river basin. The same trend is observed as to the maximum runoff.

It should be noted that the Ural river basin features a large number of hydrotechnic facilities, which can in turn affect the runoff regime and the nature of long-term runoff changes, leaving this research subject to further investigation.

\section{References}

1. A. Vtorova, N. Myakisheva, Regionalnye problemy vodopolzovaniya $v$ izmenyayushchikhsya klimaticheskikh usloviyakh, 117-122 (2014)

2. I. Alferov, N. Yakovenko, Byulleten Orenburgskogo nauchnogo tsentra UrO RAN, 2, 1-8 (2015)

3. Yu. Vinokurov, A. Chibilev, B. Krasnoyarova, V. Pavleychik, S. Platonova, Zh. Sivokhip, Izvestiya RAN. Seriya geograficheskaya, 3, 95-104 (2010)

4. Zh. Sivokhip, V. Pavleychik, Vestnik Orenburgskogo gosudarstvennogo universiteta, 13, 203-208 (2015)

5. Zh. Sivokhip, Vestnik Voronezhskogo gosudarstvennogo universiteta, 3, 87-94 (2014)

6. A. Gareev, R. Galimova, A. Minnegaliev Regionalnye problemy vodopolzovaniya $v$ izmenyayushchikhsya klimaticheskikh usloviyakh, 15-19 (2014)

7. Rodda H. J. E., Little M. A. Understanding Mathematical and Statistical Techniques in Hydrology: An Examples-based Approach, 90 (2015)

8. S. Dobrovolsky, Globalnye izmeneniya rechnogo stoka, 660 (2011)

9. Resursy poverkhnostnykh vod SSSR. Nizhnee Povolzhye i Zapadny Kazakhstan, 12, 512 (1970) 